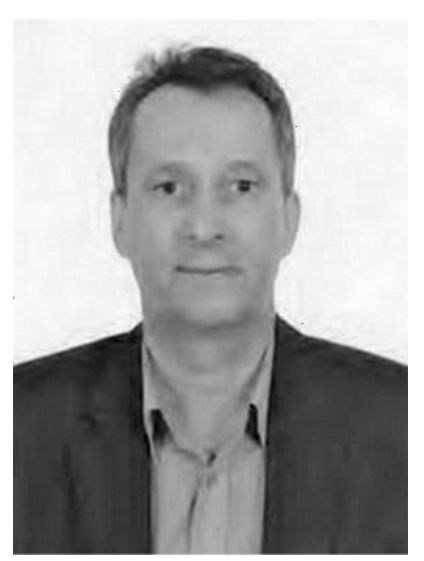

Іван Силадій,

кандидат педагогічних наук,

здобувач Національного педагогічного університету

імені М.П. Драгоманова

(м. Київ, Україна)

Ivan Syladii,

PhD in Education, Applicant

at the National Pedagogical Dragomanov University

(Kyiv, Ukraine)

\title{
РЕСУРСИ І СТИМУЛИ ПЕДАГОГІЧНОГО ДИСКУРСУ В СУЧАСНОМУ УКРАЇНСЬКОМУ СУСПІЛЬСТВІ
}

Анотація. У статті аналізуються ресурси і стимули педагогічного дискурсу в сучасному українському суспільстві, визначається його роль з огляду на виконання системою освіти загального призначення - залучення людини до досягнень культури, системи знань, процесу формування компетенцій. За визначенням автора, освіта - це насамперед процес поширення наукових знань серед тих, хто навчається, освоєння ними системи наукових понять

і духовних цінностей, яка відтворює картину природи, суспільства та мислення. Всі вони далекі від однозначності, а тому потребують інтерпретації, дискурсу.

Головним ресурсом педагогічного дискурсу є інноваційна педагогічна діяльність як особливий вид творчої діяльності, яка спрямована на оновлення системи освіти. У межах педагогічного дискурсу водночас функціонують науковий та освітній дискурс, тому потужним ресурсом дискурсу педагогічного має стати дискурс науковий. Отже, у царині освітянської комунікації педагогічний дискурс $є$ інтегрованим утворенням, яке поєднує в собі складові наукового та освітнього дискурсу.

Характерна риса сучасного етапу розвитку педагогічного дискурсу - пошук нового міжпредметного полікультурного діалогу. Педагогічний дискурс $є$ там, де відбувається інтеракція між учителем і учнем і де здійснюється пізнання. Дискурс це типова соціальна подія, що полягає у взаємодії учасників комунікації за допомогою вербальних текстів та інших знакових комплексів у певній ситуації і в певних соціокультурних умовах спілкування. Ресурсним ядром та основоположною сутнісною характеристикою педагогічного дискурсу $є$ інтелектуальна взаємодія базової пари учасників комунікації викладача і учня, кожен з яких здійснює свою інтелектуальну діяльність. Взаємодія - це вид безпосередніх чи опосередкованих, зовнішніх або внутрішніх відносин, зв'язків. Інтелектуальна взаємодія викладача й учня в педагогічному дискурсі передбачає взаємний розумовий вплив суб'єктів освітнього процесу один на одного в їх спільній діяльності і міжособистісних відносинах, що призводить до зміни інтелектуального стану одного або обох суб'єктів.

Педагогічний дискурс у структурі інноваційних процесів у системі освіти є водночас і одиницею навчання, i комунікативною моделлю мовної діяльності учасників ситуації навчання. Ця діяльність одержує мовне втілення як система думок, цінностей, інтересів. Дискурс можна вважати довершеною формою комунікації. Отже, усі наявні в суспільстві ресурси і стимули фрункціонування педагогічного дискурсу мають сприяти розгортанню взаємодії його основних суб'єктів.

Ключові слова: людина, освіта, культура, дискурс, педагогічний дискурс, ресурси педагогічного дискурсу, стимули педагогічного дискурсу, ознаки педагогічного дискурсу.

\section{PEDAGOGICAL DISCOURSE RESOURCES AND INCENTIVES IN THE MODERN UKRAINIAN SOCIETY}

Abstract. In the article, the resources and stimuli of the pedagogical discourse in modern Ukrainian society are analyzed; its role in view of the implementation by the education system of the general purpose to attract people to the achievements of culture, knowledge system, the process of forming competences. According to the author's definition, education is, first of all, the process of disseminating scientific knowledge among those who are studying, their mastering a system of scientific concepts and spiritual values that reproduces the picture of nature, society and thinking. All of them are far from unambiguous, and therefore require interpretation, discourse.

The main resource of the pedagogical discourse is innovative pedagogical activity as a special kind of creative activity aimed at updating the education system. In the framework of the pedagogical discourse, at the same time, a scientific and an educational discourses function, therefore a scientific discourse should become a powerful resource of the pedagogical discourse. Thus, in the field of educational communication, the pedagogical discourse is an integrated entity that combines the components of scientific and educational discourse.

A characteristic feature of the present stage of the development of the pedagogical discourse is search for a new interdisciplinary multicultural dialogue. The pedagogical discourse is where interactions between a teacher and a student occur 
and where cognition is carried out. A discourse is a typical social event that involves the interaction of communication participants through verbal texts and other sign complexes in a particular situation and in certain socio-cultural conditions of communication.

The resource core and the fundamental essential characteristic of the pedagogical discourse is intellectual interaction of the basic pair of communication participants - a teacher and a student, each of whom carries out his intellectual activity. Interaction is a type of direct or indirect, external or internal relations, relation ships. The intellectual interaction of the teacher and the student in the pedagogical discourse involves the mutual mental influence of the subjects of the educational process on each other in their common activity and interpersonal relations that leads to a change in the intellectual state of one or both subjects.

The pedagogical discourse in the structure of innovative processes in the education system is at the same time a unit of study, and a communicative model of verbal activity of the participants in the educational situation. This activity receives verbal performance as a system of ideas, values and interests. A discourse can be considered a perfect form of communication. Consequently, all resources and incentives for the functioning of the pedagogical discourse available in the society should contribute to the development of the interaction of its main actors.

Keywords: person, education, culture, discourse, pedagogical discourse, resources of the pedagogical discourse, stimuli of the pedagogical discourse, signs of the pedagogical discourse.

\section{ВСТУП}

Постановка проблеми. Жодна культура сама по собі не спроможна розкрити всієї багатогранності суспільства, не спроможна створити універсальної системи цінностей планетарного характеру. Універсальна за своєю природою нова парадигма освіти постійно потребує синтезу, діалогу культур як суттєвого джерела збагачення й розвитку особистості [9, с. 89].

У зв'язку з цим останнім часом спостерігається активізація наукових досліджень в галузі дискурсу і формування дискурсивної компетенції, яка позиціонується в якості однієї з ключових компетенцій, визнаних Радою Європи. Разом з тим, своєрідний «розкид» досліджень, пов'язаних із проблемою трактування понять «дискурс» і «педагогічний дискурс», призводить до неоднозначності і суперечливості у вирішенні названої проблеми. Дискурс визначається в сучасній лінгвістичній теорії як складне комунікативне явище, яке разом з лінгвістичними характеристиками, властивими тексту, має і екстралінгвістичні параметри (учасники комунікації, їх комунікативні цілі, наміри, прагматичні установки, соціальні ролі, фонові знання про умови спілкування: про співрозмовника, час, простір) [11, с. 84].

\section{МЕТА I ЗАВДАННЯ ДОСЛІДЖЕННЯ}

Метою статті $\epsilon$ аналіз ресурсів і стимулів педагогічного дискурсу в сучасному українському суспільстві, визначення його ролі з огляду на виконання системою освіти загального призначення - залучення людини до досягнень культури, системи знань, процесу формування компетенцій.

\section{РЕЗУЛЬТАТИ ДОСЛІДЖЕННЯ}

Головним ресурсом педагогічного дискурсу є інноваційна педагогічна діяльність як особливий вид творчої діяльності, яка спрямована на оновлення системи освіти. Вона є результатом активності людини не стільки у пристосуванні до зовнішнього середовища, скільки у зміні його відповідно до особистих і суспільних потреб та інтересів. Як складний і багатоплановий феномен інноваційна діяльність, за визначенням О. С. Скубашевської, охоплює процес взаємодії індивідів, спрямована на розвиток, перетворення об'єкта, на переведення його в якісно новий стан; системну діяльність щодо створення, освоєння та застосування нових засобів; особливий вид творчої діяльності, що об'єднує різноманітні операції і дії, спрямовані на здобуття нових знань, технологій, систем [10, с. 203].

Характерна риса сучасного етапу розвитку педагогічного дискурсу - пошук нового міжпредметного полікультурного діалогу. Діалогічне мислення, яке постає метою такого інтегративного міждисциплінарного підходу, сприяє формуванню нової світоглядної позиції, базованої на визнанні різноманітності світу, багатогранної складності соціокультурних процесів. Як зазначає В. Морозов, процес сприйняття й свідомого осмислення іншого культурного простору не лінійний, а швидше багатовекторний. Діалогізація змісту особистісно-орієнтованого освітнього простору базується на принципі діалогу культур різних історичних епох та діалогу різних національних культур на одному часовому зрізі [4, с. 36].

Безумовно, першою і єдиною ресурсною умовою дискурсу є діалог. Але в системі педагогічного дискурсу до діалогу висувається низка вимог, які випливають із вкрай своєрідної позиції саме педагогічного дискурсу в системі інших інституціональних та індивідуальних дискурсів. По-перше, педагогічний дискурс характеризується автономністю як тип дискурсу в силу об'єктивної наступності соціокультурного досвіду, тобто в силу, з одного боку, дій індивідів, що передають знання, ідеї, цінності, і, з іншого боку, дій та зусиль індивідів, які ці знання отримують. У цьому сенсі педагогічний дискурс є там, де відбувається інтеракція між учителем і учнем і де здійснюється пізнання. Власне, наявність цих двох умов обумовлює і цілі дискурсу, які принципово залежать від особливостей когнітивних процесів учнів і характеру навчально-виховної взаємодії, його текстів, предметної галузі тощо.

По-друге, проблема педагогічного дискурсу, як визначає $€$. Кожемякін, має два аспекти [1, с. 44]. 3 одного боку, вона виражається в пошуку та реалізації адекватних когнітивних і комунікативних засобів, які репрезентують ідеали освіти (професійні, культурні, екзистенційні) та конструюють ідентичності (професійні, соціокультурні, особистісні). 3 іншого, вона пов'язана із суперечністю між індивідуально-особистісними інтенціями, здібностями, світовідчуттям, досвідом і уніфікується характером інституційної дії освіти. Ця проблема проявляється, зокрема, як розрізнення базових предметів дискурсу («індивід» і «особистість»), як конфлікт між самосприйняттям учня і його педагогічною описовою «моделлю», як неузгодженість між екзистенційним 
контекстом дискурсу і «виробництвом соціального суб'єкта». У цьому сенсі педагогічна дискурсна практика виражається в свого роду «протиборстві» між аудиторними і адміністративними регулятивними процесами.

По-третє, освіта навчає індивіда не тільки володіти певними цінностями, знаннями, навичками, а й постачає йому необхідні лінгвістичні форми у вигляді текстів і формує навички їх відтворення, чим легітимізує його право на вираження певної думки в рамках доступного і виправданого інституціоналізованого дискурсу. «Говорячи метафорично, в ході освітньо-педагогічної практики індивід наділяється «правом підпису», навчившись відтворювати інституціональні та соціокультурні відносини. На мій погляд, з цією особливістю пов'язана одна небезпека, що виражається в тому, що в дискурсі «право підпису» може ставати кінцевою метою освіти, підпорядковуючи собі завдання формування компетентності. Іншими словами, формула «я можу побудувати будинок, тому я будівельник» може заміщатися формулою «я здобув освіту будівельника, тому можу будувати будинок». Це принципово спотворює цінності освіти і свідчить про явні чи латентні дискурсні деформації, при яких створення соціального агента стає головним завданням та елімінуються когнітивні функції освіти» [1, с. 45]. Це висловлювання Є. Кожемякіна окреслює наявний стан речей в українській системі освіти, де дискурс будується навколо визначення певних соціальних ролей, підкріплених фрормальними ознаками (дипломом, атестатом), а не змістовними характеристиками знання. Таким чином потужний потенціал педагогічного дискурсу марнується за рахунок надмірної стандартизації та контролю з боку вищих інстанцій, які здебільшого суб'єктами цього дискурсу виступають лише формально.

У межах педагогічного дискурсу водночас функціонують науковий та освітній дискурс, тому потужним ресурсом дискурсу педагогічного має стати дискурс науковий. Науковці окреслюють сфери використання освітнього та наукового дискурсу, зокрема зазначаючи, що метою освітнього дискурсу $є$ соціалізація майбутніх фахівців, а процес одержання нового знання відбувається в межах наукового дискурсу. При цьому наукове знання як результат пізнавальної діяльності суб'єктів науки проходить процес вербалізації в освітній практиці [12, с. 25]. Учасники педагогічного дискурсу взаємодіють як компліментарно (освітній дискурс), так і симетрично, що характерно для наукового дискурсу. Цінності виводяться із сукупності морально-етичних норм суспільства, регулюють ті чи інші відносини людей, виступаючи засобами й об'єктами їх діяльності. Цінності наукового дискурсу пов'язані з корисними відомостями і концентруються переважно в концептах «істина», «знання», «дослідження». Отже, можемо дійти висновку, що у царині освітянської комунікації педагогічний дискурс є інтегрованим утворенням, яке поєднує в собі складові наукового та освітнього дискурсу в такому контексті, в якому їх неможливо чітко розмежувати.

Спираючись на розуміння дискурсу як сукупності мовленнєво-мисленнєвих дій суб'єктів, що вступають у комунікацію, обумовлених метою та завданнями навчально-виховного процесу і конкретною педагогічною ситуацією, комуніканти, або суб'єкти освітнього процесу, сприймають об'єктивну педагогічну дійсність, проектують їі у свою свідомість, а відтак формалізують її за допомогою мовних засобів згідно з конкретною педагогічною ситуацією. У такому розумінні дискурс - це типова соціальна подія, що полягає у взаємодії учасників комунікації за допомогою вербальних текстів та інших знакових комплексів у певній ситуації і в певних соціокультурних умовах спілкування [3]. Перед цією взаємодією та під час ії учасники формують певні стратегії педагогічного дискурсу, які складаються з комунікативних інтенцій, що конкретизують його основну мету. Ціннісна складова педагогічного дискурсу проявляється в залученні нового члена суспільства до культурних цінностей соціуму, повідомленні інфрормації про норми і правила мовної і немовної поведінки, прийняті у суспільстві. Цінності педагогічного дискурсу відповідають цінностям соціалізації як суспільного явища.

Отже, ресурсним ядром педагогічного дискурсу є інтелектуальна взаємодія базової пари учасників комунікації викладача і учня, кожен з яких здійснює свою інтелектуальну діяльність. Інтелектуальна діяльність викладача полягає в передачі знань, обміні інформацією з учнями, управлінні їх пізнавально-практичною діяльністю і регулюванні взаємовідносин між ними. Інтелектуальна діяльність учня - це сприйняття інформації, що транслюється викладачем (або міститься в навчальних посібниках), її переробка, засвоєння і ретрансляція [8, с. 307]. Навчальний дискурс є діалог у широкому значенні цього слова, який, за М. М. Бахтіним, може бути нескінченно продовжений і в нього можуть вступати нові учасники комунікації за необхідності проходження загальної інтенції типової взаємодії і схемі організації акту навчальної комунікації. У смисловому і формальному плані педагогічний дискурс відображає реальну ситуацію (референтно-наочну і комунікативну), попередні знання, а також передаванні їм знання, що припускає зверненість до подальшого досвіду [2, с. 9].

Однак основоположною сутнісною характеристикою педагогічного дискурсу все ж є категорія взаємодії. Взаємодія - це вид безпосередніх чи опосередкованих, зовнішніх або внутрішніх відносин, зв'язків. Інституційний дискурс як сфрера професійного спілкування характеризується інтелектуальною взаємодією людей, яка являє собою обмін інформацією в їх спільній професійній діяльності та особистісній взаємодії - співробітництві. Інтелектуальну взаємодію слід відрізняти від буденного спілкування, оскільки її метою є спільне вироблення певного інтелектуального продукту - результату обміну інформацією в спільній розумовій професійно-орієнтованій діяльності суб'єктів взаємодії, її творчої переробки, інтерпретації та мовної об'єктивації [8, с. 305].

Інтелектуальна взаємодія викладача й учня в педагогічному дискурсі передбачає взаємний розумовий вплив суб'єктів освітнього процесу один на одного в їх спільній (навчальній, педагогічній та навчальній) діяльності і міжособистісних відносинах, що призводить до зміни інтелектуального стану одного або обох суб'єктів. Інтелектуальним продуктом такої взаємодії можуть виступати судження, умовиводи, твори, доповіді, проекти тощо. Інтелектуальна взаємодія викладача й учня соціально орієнтована і припускає асиметричні 
(статусні) відносини, оскільки суб'єкти взаємодії виконують різні соціальні ролі. Такий вид взаємодії може мати односпрямований і взаємоспрямований вектори. У педагогіці односпрямований вектор був свого часу притаманний авторитарній парадигмі взаємодії - педагогічний вплив педагога на учня як обумовленість поведінки дитини діями дорослого («суб'єкт педагог - об'єкт учень») [8, с. 306]. Сучасна українська система освіти намагається будуватися в рамках «суб'єктно-суб'єктної» педагогічної парадигми («суб'єкт педагог - суб'єкт учень»), що ґрунтується на принципі спільної ціннісної діяльності.

Треба визнати, що сучасна теорія дискурсу в педагогіці - це не тільки накопичення і систематизація фрактів, що виділяються як значущі, такі, що потребують уваги і визначають перспективність дослідницьких напрямів. Педагогічний дискурс - це відображення якісно інших відносин між фактами, які не залишають досліднику можливості при висуненні ідей, гіпотез, положень тощо перебувати поза новими онтологічними

і методологічними перспективами пізнання. Зіткнення безлічі смислів, сполучених з поняттям «дискурс» у педагогіці, дозволяє розкрити неоднозначність розуміння його часових і просторових локусів (обмеженість рамками уроку, лекції чи освітнього простору регіону), механізмів генерування дискурсу і позиціонування в його просторі. Конкретизація поняття «дискурс» у педагогіці на сучасному етапі розвитку пов'язана не стільки з пошуком вичерпного і усередненого визначення, скільки із закріпленням за ними певного змісту [7, с. 27]. Сучасний педагогічний дискурс оперує різними контекстами, апелюючи до нової інфрормаційної ситуації і перетворення знань на безпосередню продуктивну силу.

Педагогічний дискурс у структурі інноваційних процесів у системі освіти є водночас і одиницею навчання, і комунікативною моделлю мовної діяльності учасників ситуації навчання з віддзеркалення подій, фрактів, реалій наочно-референтної ситуації відповідно до їх внутрішнього світу. Ця діяльність одержує мовне втілення як система думок, цінностей, інтересів, оскільки оброблене свідомістю індивіда об'єктивне виражається у мовному коді як його суб'єктивне відображення та інтерпретація. Першочерговою умовою реального життя навчального дискурсу є проходження спільності: а) наочно-референтної ситуації; б) зіставлення логічно вивірених суджень дискурсантів; в) доказовість суджень і пропозицій; г) висока раціональність технології дискурсу [2, с. 11]. Суб'єкт, залучений до педагогічного дискурсу, мимоволі розширює не тільки сферу своєї навчальної діяльності, а й долучається до всієї повноти дискурсних та комунікаційних подій відповідної спільноти, культури, соціуму.

Підводячи підсумок, можна зазначити, що аналіз основних ознак педагогічного дискурсу дає змогу виявити такі його особливості, які полягають у:

- своєрідній суспільній меті (соціалізації члена суспільства, розширенні його пізнавальних можливостей в організованому навчальному процесі);

- особливостях психологічних характеристик суб'єктів педагогічного спілкування, що виявляються в мотивації діяльності (наприклад, пов'язаної з навчанням мови чи опануванням мови для подальшого становлення особистості);

- хронотопі (єдності часу й місця, які характеризують те чи інше спеціально організоване заняття);

- цінностях, притаманних цьому виду спілкування як основі формування світогляду учня (шанобливе ставлення до слова);

- жанрах педагогічної комунікації (урок, семінар, лекція, тематичний вечір, екскурсія тощо);

- своєрідних прецедентних текстах (тексти підручників, прислів'я, приказки, загадки відповідної тематики, навчальні пам'ятки, схеми мовного аналізу тощо);

- особливостях застосування педагогічних стратегій [6]. Виходячи з цих засновків, можна вести мову про соціокультурні ефекти педагогічного дискурсу як відносно окремих індивідів і малих соціальних груп, так і у відношенні до великих соціальних спільнот і суспільства в цілому [5, с. 31].

Дискурс можна вважати довершеною формою комунікації. У наш час поняття про дискурс перетворилося на ключовий концепт методології гуманітарних наук, а загальне вчення про дискурси $є$ джерелом плідних інтуїцій, експлікація яких призвела до появи нового трансдисциплінарного концептуального апарату дискурс-аналітичних досліджень. Л. Б. Колток у своєму дисертаційному дослідженні наводить його різноманітні визначення: надфразовий взаємозв'язок (єдність) слів; самоузгоджений текст; усно-розмовна фрорма тексту; взаємодія, інтеракція між особистостями; діалог; полілог; мовленнєва практика; група висловлювань, пов'язаних між собою за змістом; мовний твір, тобто письмова або усна даність думки; «мова у мові»; граматично фіксований спосіб знакового закріплення соціокультурних смислів [2, с. 7].

\section{ВИСНОВКИ}

Здійснений аналіз дозволяє дійти висновку про те, що педагогічний дискурс - це об'єктивно існуюча динамічна система ціннісно-смислової комунікації суб'єктів освітнього процесу, яка функціонує в освітньому середовищі і включає учасників дискурсу, педагогічні цілі, цінності та змістовну складову, що забезпечує підготовку компетентного фахівця, здатного вільно орієнтуватися в різних сферах соціальної і професійної діяльності. Педагогічний дискурс покликаний зіграти істотну роль у функціонуванні та розвитку системної сукупності засобів, що залучаються для оптимізації освітнього процесу, результатом якого $є$ не тільки засвоєння змісту освіти, але й розвиток особистості. 


\section{СПИСОК ВИКОРИСТАНИХ ДЖЕРЕЛ}

[1] Кожемякин Е. Образовательно-педагогический дискурс. Современный дискурс-анализ : Электронный журнал. 2010. Вып. 2. T.1. C. 27-47. URL: discourseanalysis.orgsada2_1.pdf

[2] Колток Л. Б. Педагогічний дискурс як засіб інтенсифікації навчально-виховного процесу в сучасній вищій школі: Автореф. дисс... канд. пед. наук 13.00.04 / Нац. пед. ун-т ім. М.П. Драгоманова. К., 2009. 22 с.

[3] Мельник Т. В. Навчально-педагогічний дискурс як типізована соціально-культурна взаємодія. Науковий вісник Донбасу : електрон. наук. фах. вид. / Луган. нац. ун-т ім. Т. Шевченка. 2013. № 2. URL: http://nbuv.gov.ua/j-pdf/nvd_2013_2_30.pdf

[4] Морозов В. Педагогічний процес як предмет педагогічного дискурсу. Вісник Інституту розвитку дитини. Сер.: Філософія, педагогіка, психологія: 3б. наук. праць / Нац. пед. ун-т ім. М. П. Драгоманова. К. : Вид-во НПУ ім. М.П. Драгоманова, 2013. Вип. 30. С. $35-41$.

[5] Москалик Г. Ф. Комунікація в умовах модернізації освіти: педагогічний дискурс. Педагогічний процес: теорія і практика. 2014. № 1. C. 28-34.

[6] Нікітіна А. В. Ознайомлення студентів-філологів з основними поняттями педагогічного дискурсу. Науковий вісник Донбасу : електр. наук. фах. вид. 2010. № 1. URL: http://nbuv.gov.ua/j-pdf/nvd_2010_1_6.pdf

[7] Пичугина В. К. Дискурс как педагогическое понятие: методологический и эвристический потенциалы. Известия Волго-градского гос. пед. ун-та. 2012. № 10. Т. 74. С. 25-28.

[8] Поспелова Ю. Ю. Педагогический дискурс и его характеристики. Вестник КгУ им. Н. А. Некрасова. 2009. Вып. 1. Т. 15. С. 307310.

[9] Романенко М. І. Освіта як об'єкт соціально-філософського аналізу; [монограф]. Дніпропетровськ: Промінь, 1998.132 с.

[10] Скубашевська О. С. Педагогічний дискурс в інноваційній стратегії розвитку освіти. Мультиверсум. Філософрський альма-нах: Зб. наук. пр. К., 2008. Вип. 67. С. 201-215.

[11] Суворова С. Л. Феноменология исследования понятий «дискурс» и «педагогический дискурс». Вестник Южно-Уральского гос. ун-та. Сер. : Образование. Педагогические науки. 2012. Вып. № 4 (263). С. 84-87.

[12] Чернявская В. Е. Интерпретация научного текста: учебное пособие для вузов. 5-е изд. стереотип. М.: КомКнига, 2009. $128 \mathrm{c}$.

\section{REFERENCES (TRANSLATED AND TRANSLITERATED)}

[1] Kozhemjakyn E. Obrazovateljno-pedaghoghycheskyj dyskurs (Educational and pedagogical discourse). Sovremennyj dyskurs-analyz : Эlektronnyj zhurnal. 2010. Vyp. 2. T.1. S. 27-47. URL: discourseanalysis.orgrada2_1.pdf (in Russian)

[2] Koltok L. B. Pedaghoghichnyj dyskurs jak zasib intensyfikaciji navchaljno-vykhovnogho procesu v suchasnij vyshhij shkoli (Pedagogical Discourse as a Means to Intensify the Educational Process in a Modern High School): Avtoref. dyss... kand. ped. nauk 13.00.04 / Nac. ped. un-t im. M.P. Draghomanova. K., 2009. 22 s. (in Ukrainian)

[3] Meljnyk T. V. Navchaljno-pedaghoghichnyj dyskurs jak typizovana socialjno-kuljturna vzajemodija (Educational-pedagogical discourse as a typified socio-cultural interaction). Naukovyj visnyk Donbasu : elektron. nauk. fakh. vyd. / Lughan. nac. un-t im. T. Shevchenka. 2013. № 2. URL: http://nbuv.gov.ua/j-pdf/nvd_2013_2_30.pdf(in Ukrainian)

[4] Morozov V. Pedaghoghichnyj proces jak predmet pedaghoghichnogho dyskursu. Visnyk Instytutu rozvytku dytyny (Pedagogical process as a subject of pedagogical discourse. Bulletin of the Institute for the Development of the Child). Ser.: Filosofija, pedaghoghika, psykhologhija: Zb. nauk. pracj / Nac. ped. un-t im. M. P. Draghomanova. K. : Vyd-vo NPU im. M.P. Draghomanova, 2013. Vyp. 30. S. 35-41. (in Ukrainian)

[5] Moskalyk Gh. F. Komunikacija v umovakh modernizaciji osvity: pedaghoghichnyj dyskurs. Pedaghoghichnyj proces: teorija i praktyka (Communication in the context of modernization of education: pedagogical discourse. Pedagogical Process: Theory and Practice). 2014. № 1. S. 28-34. (in Ukrainian)

[6] Nikitina A. V. Oznajomlennja studentiv-filologhiv z osnovnymy ponjattjamy pedaghoghichnogho dyskursu (Introduction to students of philology with the basic concepts of pedagogical discourse). Naukovyj visnyk Donbasu : elektr. nauk. fakh. vyd. 2010. № 1. URL: http://nbuv.gov.ua/j-pdf/nvd_2010_1_6.pdf (in Ukrainian)

[7] Pychughyna V. K. Dyskurs kak pedaghoghycheskoe ponjatye: metodologhycheskyj y evrystycheskyj potencyaly (Discourse as a pedagogical concept: methodological and heuristic potentials). Yzvestyja Volghoghradskogho ghos. ped. un-ta. 2012 . № 10. T. 74. S. 25-28. (in Russian)

[8] Pospelova Ju. Ju. Pedaghoghycheskyj dyskurs y egho kharakterystyky (Pedagogical discourse and its characteristics). Vestnyk KGhU ym. N.A. Nekrasova. 2009. Vyp. 1. T. 15. S. 307-310. (in Russian)

[9] Romanenko M. I. Osvita jak ob'jekt socialjno-filosofsjkogho analizu (Education as an object of socio-philosophical analysis); [monoghraf]. Dnipropetrovsjk: Prominj, 1998. 132 s. (in Ukrainian)

[10] Skubashevsjka O. S. Pedaghoghichnyj dyskurs v innovacijnij strateghiji rozvytku osvity (Pedagogical Discourse in the Innovation Strategy of Education Development). Muljtyversum. Filosofsjkyj aljmanakh: Zb. nauk. pr. K., 2008. Vyp. 67. S. 201-215. (in Ukrainian)

[11] Suvorova S. L. Fenomenologhyja yssledovanyja ponjatyj «dyskurs»y «pedaghoghycheskyj dyskurs» (Phenomenology of the study of the concepts of «discourse» and «pedagogical discourse»). Vestnyk Juzhno-Uraljskogho ghos. un-ta. Ser. : Obrazovanye. Pedaghoghycheskye nauky. 2012. Vyp. № 4 (263). S. 84-87. (in Russian)

[12] Chernjavskaja V. E. Ynterpretacyja nauchnogho teksta: uchebnoe posobye dlja vuzov (Interpretation of the scientific text: a textbook for universities). 5-e yzd. stereotyp. M.: KomKnygha, 2009. 128 s. (in Russian) 